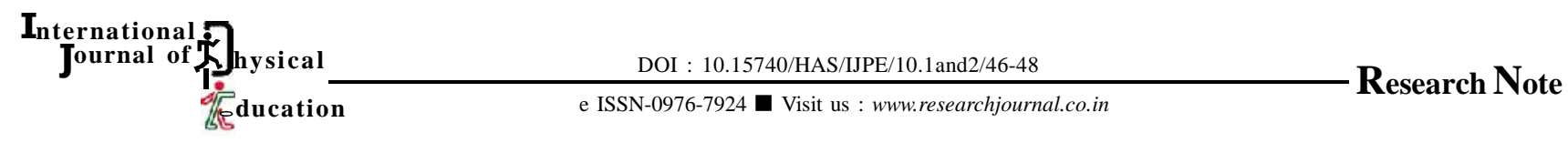

Volume 10 | Issue 1\&2 | April \& October, 2017 | 46-48

\title{
Sports person and proper nutrition
}

\section{ARJUN SINGH}

Received : 12.08.2017; Accepted : 30.09.2017

\author{
Author for correspondence \\ ARJUN SINGH \\ Department of Physical Education, \\ Dr. Ram Manohar Lohia Avadh \\ University, Faizabad (U.P.) INDIA \\ Email: arjunsinghau@gmail.com
}

- KEY WORDS : Sports person, Proper nutrition, Reference sportsman, Reference sports woman

- HOW TO CITE THIS PAPER : Singh, Arjun (2017). Sports person and proper nutrition. Internat. J. Phy. $E d u$., 10 (1\&2) : 46-48, DOI : 10.15740/HAS/IJPE/10.1and2/46-48.
I $\mathrm{t}$ is presumed that an active player or athlete spends at least four hours per day in active practice. The physical activity depends on the type of game and sport. It is also well known, that, competitive matches required more energy.

\section{Reference sportsman:}

Reference sportsman is defined as one aged 20-39 years weighing $60 \mathrm{~kg}$.in body weights and with 7-15 per cent body fat. Daily he involves himself 4 hours in moderate activity during practice. He needs $3600 \mathrm{Kcal}$ of energy per day at physiological level which can be obtained by rations giving $4320 \mathrm{Kcal}$. It includes an allowance of 20 per cent for losses during processing, kitchen and plate wastage.

\section{Reference sportswoman:}

Reference woman is between 20-39 years of age and weighing $50 \mathrm{~kg}$. She spends 4 hours in moderate activity during practice. She requires $2900 \mathrm{Kcal}$ which

\begin{tabular}{|lc|}
\hline $\begin{array}{l}\text { Table 1: Range of the daily energy consumption in the training } \\
\text { process of the deferent sports }\end{array}$ & $\mathrm{K} \mathrm{Cal./kg/day}$ \\
\hline Sports & $50-68$ \\
Gymnastics & $55-70$ \\
Sprint and middle distance runners & $60-80$ \\
\hline
\end{tabular}

she can get from ration yielding $3480 \mathrm{Kcal}$ per day. It provides for wastage/losses of 20 per cent of various levels.

\begin{tabular}{|lcc|}
\hline \multicolumn{2}{|c|}{ Table 2: Recommended dietary intake of nutrients at ration level } \\
\hline & $\begin{array}{c}\text { Reference } \\
\text { sportsman }\end{array}$ & $\begin{array}{c}\text { Reference sports } \\
\text { woman }\end{array}$ \\
\hline Net calories (Kcal.) & 4310 & 3470 \\
Protein (g) & $100-120$ & $80-100$ \\
Calcium (g) & $1-2$ & $1-2$ \\
Iron (mg) & $50-75$ & $60-100$ \\
Retinol (mg) & $1000-2000$ & $1000-2000$ \\
Thiamine (mg) & $3-4$ & $2-3$ \\
Vitamin C(mg) & $100-200$ & $100-200$ \\
Nicotinic acid (mg) & $40-50$ & $40-50$ \\
\hline
\end{tabular}

Carbohydrates can provide energy upto 50-70 per cent of the total requirement. Endurance athletes can use the upper level. Visible and non-visible fat could meet from 20 to 30 per cent of the energy needs and the lower level is suitable for endurance athletes. Proteins can supply above 10 to 15 per cent of energy and upper most limits may be $2 \mathrm{~g}$ per $\mathrm{kg}$. body weight.

Ensure adequate glycogen stores are meeting the needs of high intensity sports. Muscle and liver glycogen stores supply the glucose vital for production of anaerobic energy. It is, therefore, necessary to replenish glycogen 